\title{
A Transatlantic Perspective on Romani Thoughts, Movements, and Presence beyond Europe
}

\section{Esteban Acuña Cabanzo}

estebanacav@gmail.com

$\mathrm{PhD}$ candidate

Institute for Cultural Anthropology and European Ethnology, Freiburg University

ORCID: https://orcid.org/0000-0003-3310-8248

Esteban Acuña Cabanzo is a PhD candidate in Cultural Anthropology for the Cultures of Mobility Research Group (COME). He is currently in the process of defending his dissertation, which focuses on the history, practice, and experience of transatlantic mobilities and migrations of Romani groups and the discourses that revolve around them. Esteban also has authored several book chapters resulting from ethnographic fieldwork in Canada, Colombia, and Hungary, coedited a volume on Romani genocide remembrance and education, and recently worked as a consultant for the Colombian peace process.

\section{Critical}

Romani Studies 


\section{Abstract}

This article first aims to establish a genealogy of critical stances on knowledge construction on, about, and from Romani groups in academia. It focuses on critical perspectives that have challenged Eurocentric binary categorizations. Such categories have resulted in the historical perception of a universal "Gypsy" "non-Gypsy" divide despite the diverse contexts in which Romani identities are negotiated in daily life. The text addresses the writings of authors who have been critical of how central this divide has been to the constitution of Romani Studies as a field, most of whom have relied on insights from Edward Said's Orientalism (2003 [1978]) and other postcolonial theorizations. The theoretical insights brought into conversation come from ethnographic work with Romani individuals and groups whose mobilities exceed imagined European borders. Based on this work, the second part of the article gives an example of the consequences of Eurocentric categorizations: a review of how Romani transatlantic migration and presence in the Americas has been conceived in academic texts. To conclude, the author puts forward engagements with Romani transatlantic passages as one of the ways in which postcolonial stances can actually be operationalized in academic practice. Throughout the argument, transatlantic experiences become not only an epistemic tool but also a case study for a refined understanding of Romani life worlds.

\section{Keywords}

- Transatlantic

- Orientalism

- Postcolonialism

- Eurocentrism 
Ronald Lee: I lived two years in England, around 1971...

E: Why did you travel to England?

$R$ : I wanted to be there, to help start all of this.

E: How did you learn about the possibility of doing it? Who did you contact?

R: The Roma network. My partner Vanya, who was with me in Montreal working together as coppersmiths, his brother lived in Paris. And that's how I knew about all of this. So I got in touch with them through his brother...

Esteban Acuña Cabanzo in conversation with Ronald Lee, June 12, 2013.

\section{Introduction: Distance and Suspicion}

In 2013 I met Ronald Lee: prolific Romani writer, journalist, activist, and recently, honorary doctor at Queens University. I had been working in Toronto, gathering interviews for my doctoral thesis on Romani transatlantic mobilities and connections. Only when I reached his house in Hamilton, Ontario, did we have time to talk about his life. Sitting in his living room, we discussed his take on the situation of Romani refugees in Canada and how he became a member of the board of the Toronto Roma Community Centre. The above quote refers to his time as part of the nascent Romani activist scene in Europe in the 1960s and 1970s, a period of his life that would affect him deeply thereafter. Placing himself between two worlds, Romani and non-Romani education institutions, throughout his youth he looked forward to aid the budding movement in Europe with his experience as a Romani intellectual in Canada. Two years later he would come home discouraged. One reason he gave for returning to Canada is precisely one of the subjects of this paper: Eurocentric ideas and interests. These had materialized in European agendas by eclipsing more international approaches to Romani activism, despite historical Romani presence beyond Europe.

The purpose of this article is to shape critical insights in Romani Studies into a working genealogy. It fulfills this aim by emphasizing the role of transatlantic awareness, or consciousness, as a building block for the distance and suspicion necessary for this approach. The argument concentrates on one of the Eurocentric assumptions about which Lee became painfully aware during his journeys, an idea that has been particularly influential in knowledge production about Romani groups: even in times of Romani activism, the messy and multiple experiences that inform Roma/gadje divisions in concrete contexts where Romani lives take place have been simplified to an "us" versus "others" rhetoric detached from such realities. The principle of this divide is an intrinsic division between "Gypsies" and "non-Gypsies" that underlies even nuanced approaches to knowledge creation.

While sitting in Ronald Lee's living room, listening to his life story, and reading from his scrapbook, I was able to see how his life was inscribed by others in such binary opposition so many times:

[Ronald] Lee was born in a tent in east Montreal, his father a Russian Romany, his mother an English Romany. Just before the war he was sent off to northern England to his maternal grandmother's, and it was there that he got his schooling. But when Lee was 21 , he decided that he must go back to live as a gypsy among the gypsies. For five years he led the nomadic gypsy life 
in eastern Canada, picking up basins to plate, finding garages to work in, joining carnivals and leaving them. His quest to do something about Canadian gypsies may be wildly idealistic, but he has two weapons: he has an education, and he has kept contact with his people (Wells 1962).

He kept such articles in his scrapbook as pieces of his past but remained critical towards how their authors portrayed his own experience. Lee kept a distance from labels such as "petty thieves" or "nomadic," each part of the "Gypsy" trope. His life, like those of most of the respondents of the research that had taken me to Canada, was more complex and dynamic than such categories could suggest. Lee even put together a course for the University of Toronto with the intention to, in his words, “... demolish the mythology of the literary Gypsy, and replace it with the reality of the Roma." The critical stances that Lee developed during this process, I argue, mirror, and in fact have been aided by, active distance from and suspicion of the process of knowledge construction, fueled by his comings and goings between both geographic and discursive contexts.

The importance of these analytical practices became evident after several conversations with Ronald Lee and other thinkers who participated as respondents in my doctoral research, a multi-sited ethnography (Marcus 1995) of Romani mobilities across and beyond the Atlantic. ${ }^{[1]}$ In this endeavor, in order to shift the usual perspective from national or European borders, the Atlantic took center stage. It was conceived as geographic and social space, created by shared experiences, that also granted awareness of specificity and difference. Among the people who shared their experiences and trajectories with me were academic and empirical thinkers whose life stories provided grounded insights into how to understand Romani mobilities and im/mobilities. ${ }^{[2]}$ These included how these movements were given meaning in a constant, unequal negotiation between people who moved or stayed, and non-Romani people.

"The nomad," "the migrant," or "the refugee" have been common metaphors used to give meaning to the exchange between mobilities and im/mobilities that resulted in Romani presence in the Americas. Although inadequate and problematic, their influence is felt in every life story. Through analysis of the roles that the categories - what Lee calls "tropes" and "myths" - had on people's lives, it was possible to add nuance and continuity to descriptions and analyses of Romani presence in the Americas which ahistorical metaphors did not provide. Such findings, I argue, also provide insights for Romani Studies as a whole, since they speak to critical self-reflection; the need to be aware of, and to deal with, presuppositions, power relations, and biases.

To exemplify this approach, this article details the consequences of Eurocentric categorizations in theoretical models, through a review of how Romani arrivals to the Americas have been understood

\footnotetext{
1 This article is based on sections of the author's doctoral thesis. The goal of the dissertation was to describe the intertwined practices, experiences, and discourses that comprise Romani mobilities across and beyond the Atlantic. The methodology employed was a multi-sited ethnography, aided by trajectory interviews, participant observation, and discourse tracing. Three sites, hubs in Romani networks, were selected as starting points for following strategies (Marcus 1995): Bogota, Budapest, and Toronto. Several biographies were selected to exemplify Romani mobilities in each setting. Ronald Lee's own life story was one of the main examples in which changing epistemic contexts motivated a critical awareness that reflected on his own intellectual approach, which was key for the project's theoretical contribution.
}

2 Mobilities and im/mobilities can be understood here as comprehensive terms that deal with experiences, practices, and discourses of human movement and stasis, in this case from a Romani standpoint (see Acuña, forthcoming). 
in academic texts. While weaving together the historical context for my dissertation, these recurrent metaphors were ubiquitous. The specific critical framework that was developed to tackle them became the first building block for sections two and three of this article. Section two is devoted to a description of concepts from critical studies of representation and race that have made their way into Romani Studies and that inform my stance. Section three details the proposed genealogy that details how critical studies have informed Romani Studies. The fourth section gives an example of how the principles identified in the genealogy inform research through a description of how transatlantic journeys of Romani people have been studied. Finally, the conclusion reaffirms that a transatlantic perspective has granted, since critical theories have informed the discipline, continuous insights into how the "Gypsy"/"non-Gypsy" divide underlies most academic understandings of Romani lives. Such awareness adds to current trends in Critical Romani Studies and becomes an asset: a way to grasp complex lived experiences and histories.

\section{Orientalism, European Particularisms, and Transatlantic Disconformity}

This proposal arises from work with, in-between, and among Romani groups with histories of movement between Europe and the Americas, groups whose community formation processes have transcended imagined European borders. I argue that constructions such as the "Gypsy"/"non-Gypsy" divide have a "special place in European Western experience" (Said 2003). This divide resembles Edward Said's analysis of "the Orient" as opposed to "the Occident." The relationship between opposite poles is based on inequality, on the subordination of one to the hegemonic other. A transatlantic perspective implies exchanges and connections between discursive contexts where these oppositions are shaped in different ways. Therefore, it aids efforts to describe and analyze the productive sensibilities to power inequalities in knowledge production. The argument echoes the call to "provincialize Europe" (Chakrabarty 2000) by thinking and weaving together locations, peoples, discourses, and concepts that have been kept apart by the powerful epistemologies sustained by the institution of "Western" or "North Atlantic" academia. In the case of this article, it became important to incorporate knowledge-building efforts on either side of the "Gypsy"/"non-Gypsy" gap.

Underlying these divides, as Cultural Studies scholars have noted, are "racializing discourses" which reduce human difference and experience to "binary oppositions" (Hall 2003, 243). In this framework one category always is assumed to be above the other, while the other is marked in people's embodied experiences. In Paul Gilroy's words:

The especially crude and reductive notions of culture that form the substance of racial politics today are clearly associated with an older discourse of racial and ethnic difference which is everywhere entangled in the history of the idea of culture in the modern West. [...] European particularisms are still being translated into absolute, universal standards for human achievement, norms and aspirations (1993, 7-8). 
The need for universal standards designed to fix and naturalize difference is explained by Michel Trouillot as "geographies of imagination." These discursive structures have allowed for the expansion of "the West" into the rest, justifying a "global geography of management" that gears power-wielding institutions and regimes towards active attempts to control what is perceived as "other" (Trouillot 2003, 2). In this framework, the Atlantic remained a crucial site for colonialism and imperialism, a site where acts of constant imposition brought instability, and with it the awareness of otherwise naturalized hierarchies. As Ronald Lee learned to his own disappointment, for Romani groups this has meant a transnational dispersion that can enable strong ties and connections but can also bring considerable differences and friction.

The genealogy in this article covers a selection of the small number of authors in English-speaking Romani Studies who have assumed critical positions in their work. They are placed in a framework that considers transatlantic experiences as a possible source of critical disconformity; “... one single, complex unit of analysis in their discussions of the modern world [useful] to produce an explicitly transnational and intercultural perspective" (Gilroy 1993, 15). I have chosen to take into account scholars who could be characterized as: (1) transatlantic "Romani intellectuals" as Ronald Lee describes himself, or Romani thinkers, my preferred use given its wider meaning; ${ }^{[3]}$ (2) transatlantic non-Romani scholars; and (3) critical scholars that focus on particular epistemic communities in their own localities. This fluid analytical classification is employed as a way to group the wide array of works that I argue are useful to understand the politics of knowledge from, on, and about Romani groups. It is a guide to note the difference in approaches that will be considered below, although all needed to be included for a comprehensive review.

This grouping has been designed to describe the complex Romani and non-Romani experiences and interconnections, immersed in power relations, that have inspired critical thought in Romani Studies. The first category includes Ronald Lee and a growing number of authors who are immersed in Romani networks themselves. Their experiences of changing epistemic contexts from one side of the Atlantic to the other have indeed impacted their own critical approach to thought and scholarship. The second grouping includes authors who, although through a non-Romani gaze, have been able to place their preconceptions into perspective. This in great measure thanks to the unique standpoint of being part of scholarly communities in both Europe and the Americas. Finally, the third group gathers the evergrowing number of critical scholars who, from their own localities and grounded work, have begun to question issues of power and knowledge. All three share a will to make Eurocentrism visible, even when this has been an uncomfortable topic for academic disciplines which historically pushed such reflections to the margins. They also share a will to prioritize interconnections between peoples, places, and ideas, instead of assuming racial and other binary categorizations. Their writings are an account of the silence, fear, and isolation that such assumptions have caused. They are also an introduction into the lived experiences of Romani peoples, and the consequences of such discourses of difference - and often of misunderstanding, terror, and hatred (Taussig 1987, 8-9). Keeping in mind the concepts and principles of critical approaches detailed in this section, the following genealogy presents how they have been employed in Romani Studies in the last four decades.

3 Although in this article I concentrate mostly on scholars, a "Romani thinker" category also allows for the recognition of knowledge creation outside of academia, which has been the inspiration for plenty of the insights compiled in this article. 


\section{A Genealogy of Critical Stances towards Representation in Romani Studies}

\section{0 s and 1980 s}

The 1970s and 1980s saw the popularization of studies on how representations went hand in hand with power relations, provoked by works such as Said's Orientalism (1978). During this time, Judith Okely was the first to write extensively about misrepresentation of the British "Traveling-Gypsies" she described in her influential The Traveller Gypsies (Okely 1983). From the perspective of social anthropology, she laid the groundwork for understanding the assumptions that were implicit in how Romani groups have been represented historically. Okely focused on one of the components of the "Gypsy"/"non-Gypsy" divide, that of understanding the "Gypsy" category as opposed to modernity. She problematized the notion of isolation implicit in previous understandings of "Gypsies" as only "one culture." It is important to note the limits of her approach, mainly downplaying shared Romani experiences beyond stigmatization and isolation, including a shared language, as well as scholarship that has focused on that front (Matras 2004). As noted in the previous section, her emphasis, although localized, lies in the unequal relations of her respondents with others, especially governmental institutions, through the space of the camp. It is no coincidence that close encounters between a feminist anthropologist and Romani groups would result in such insights on representation, together with positionality, key trends for critical Romani Studies in the following decades (Okely 2011 and 2014).

\section{$1990 s$}

During the 1990s another series of encounters between Romani and critical academic thought occurred. Katie Trumpener started to unravel these processes as she studied Romani literature, concretely, Goddam Gypsy, Ronald Lee's autobiographical novel. Lee's life course had inspired Trumpener to understand how ideas about Romani peoples had consequences in action. In her words: "there has, to date, been little corresponding literary, cultural, or political analysis of the racism and Orientalism historically surrounding the Western construction of the 'Gypsy Question"' (Trumpener 1992, 848). As a precursor, Trumpener took the first steps in theorizing what she calls the "linked apparatuses of repression and representation." Images such as the carefree "nomad" or the backwards "noble savage" within Europe historically have been used to justify a brutal history of oppression. In this discursive realm, "Gypsy life [is seen] as a carefree, defiant, disruptive alternative to Western culture" $(1992,860)$. She notes how "Gypsies" have been relegated, like other populations, to a realm outside of time, history, and writing, outside of "the West," and as such cannot be part of modern societies. Their lives demand intervention, either through betterment or civilizing projects, and often through violence. What I deem her main contribution is her engagement with literature, not only about Romani groups but also authored by them. In this way she steps out of postmodern solipsism into Ronald Lee's exploration of alternative representations of Romani lives and realities in the midst of such exclusion.

This step was missing in the field, given the proclivity of other academics in the European circuit to rely mostly on sources written about Romani groups. Looking through this lens, names such as Willems come 
to mind, ${ }^{[4]}$ who had called into question what he considers a "one-dimensional picture" to determine who is a "true Gypsy": "In contemporary socio-historical research [...] they [Gypsies] only make the scene in a context of penury, mendacity, vagabondage, marginality and criminality" (Willems 1997, 9), another aspect of the "Gypsy" trope. Unfortunately, the limits of engaging only with historical sources and his aversion to Romani politics precluded him from noting that across the ocean, his critique overlapped with that of Ian Hancock in the 1980s: "It is presumptuous to assume that Rom need to be told how to manage their own affairs, and who is or is not a Rom" (Hancock 2010, 40-41). The only alternative Willems provided was to turn our eyes to "integration" processes, which tend to assume the familiar binary fracture mentioned earlier by situating Romani groups as a "them" that need to be integrated into "us," despite centuries of shared histories.

On the other side, the purpose of Hancock's writings in the early 1990s seems to have been to use scholarship to dive into the ambivalence between diversity and unity that "romanipe ("Gypsiness")" entails (Hancock 1991, 254). It was important for him to discuss both the gaze of the "gadzé" (non-Roma) and the sense of unity in diversity that underlies belonging to Romani groups. Based on the history of and his own experience participating in - Romani self-organization in both Europe and the Americas, Hancock opened another window to critical assessments of representations in Romani Studies: "When non-Gypsies go from wagon to automobile, it's called progress, when Gypsies do the same thing, it's a disappointment" (Hancock 1991, 255).

Later in that decade he emphasizes what he calls "prejudice" evident in the reduction of "Gypsies" to "images" that have more to do with a Western canon of representation than actual Romani lives (Hancock 1997). The anecdotes that he uses to explain this point include the encounters of American scholars with racial categorizations in Europe ${ }^{[5]}$ a recurrent circumstance that will continue feeding this trend of scholarship. Hancock continues to rely on his own experience in order to include agency into his reflections. He details how Romani people around him react to these images, hiding their belonging, or having to face prejudice evident in daily life and expert discourse, including attempts to challenge these fictions.

\section{The Turn of the Century}

A continuation of Trumpener's and Hancock's projects came from Australia as Romani-Irish Ken Lee took Said's premises further. His writings made explicit the place of the "Gypsy" and "Gypsylorism" in orientalist discourse; "the construction of the exotic Other within Europe" as opposed to "Orientalism" which mostly dealt with "the exotic Other outside Europe" (Lee 2000, 132; Selling 2018, 49). There were intimate relations between the creation of "The Orient" as subject and that of "The Gypsies", an oriental

4 Note that Willems's work has been grouped with that of Leo Lucassen and Anna Marie Cottaar in the so-called "Dutch School," which was one of the first to bring Michel Foucault's thoughts to Romani Studies (see Lucassen et al. 1998; Stewart 2013, 423-424). Unfortunately, the scholars associated with this school are usually only given credit for noting the importance of power relations in the construction of Romani ethnic identity. What is usually not mentioned is how they managed to put a mirror to the academic craft in Romani Studies and its connection with the practice of governance in Europe.

5 Hancock cites the example of Diane Tong's visit to Greece. The author of Gypsy Folk Tales encountered normalized racism in an orthodox priest who brushed aside comparisons between racism in the United States and the situation of Romani people in Thessaloniki (Hancock 1997). 
manifestation inside the European continent. Lee is keen to note how this premise feeds knowledge creation about people labelled as such and serves institutions to manage their governance.

Together with Ronald Lee, Ian Hancock, and other Romani thinkers, Ken Lee criticized and confronted institutions such as the Gypsy Lore Society (GLS). After an 18 year gap, this same organization relaunched its journal in 2000 under a new banner, changing its title from the Journal of the Gypsy Lore Society, published until 1982, to Romani Studies. Anthropologists Gropper and Miller (2001) used the opportunity to engage the topic of knowledge production as well, especially questioning ethnographic authority: "We scholars are in error when we assume that the Roma have had only a passive role in this process" $(2001,107)$. Their text did not address, however, the continuity of these reflections or relate their criticism to others in Europe and beyond. Ken Lee did engage with his European counterparts, while also engaging with reflexive anthropology. His writings reflect upon questions of power at the center of ethnography, including the use of text to negate a group's coevalness with "the West," that is, its participation in modernity and the present time (Fabian 2002) or as a way to fixate, preserve, and standardize the dynamism of orality through writing (Lee 2000, 144).

Ronald Lee's work was published simultaneously with that of other transatlantic scholars who focused on performance and performativity; the actual things that representations do. While Sonnemann (1999) mapped the "migrating metaphor of the Gypsy" throughout literature, ethnomusicologists such as Van de Port analyzed how these metaphors actually were built in daily interactions. Through his work in Serbia, this author notes how "Gypsyness" is then a "construct on the perceivers' part, but which is elaborated and commodified by Gypsy musicians" (Van de Port 1999, 292). Lemon, another ethnographer working in Russia, delved deeper. Her writings went to the very heart of the "Gypsy"|"majority" divide, bringing together the construction of an ideal, Orientalized "Gypsy" with quotidian practices of "authenticity" and "tradition." "Gypsies have [...] been ascribed a reputation as natural performers" (Lemon 2000, 4) - performers of the very exotic and romantic ideals that sustain that gap. "Roma who do not engage in such work are seen to be assimilated or as no longer authentic" (ibid.). This realization is key for understanding the consequences of the categories created through the work of experts (academic and otherwise).

\section{The First Decade of the Twenty-first Century}

It is difficult to understate the importance of these early writings on "Gypsy" representations, since they opened the gates to a number of collections and articles with these constructions in mind (see Lyon 2004; Saul and Tebbutt 2004; Glajar and Radulescu 2008; the 2008 edition of Third Text: Picturing Gypsies: Interdisciplinary Approaches to Roma Representation; and Dearing 2010). It is also important to note how some of these works were pioneers in emphasizing the need for an assessment of "whiteness." Anikó Imre, in this vein, uses the case of the representation of Romani groups in post-socialist Eastern Europe to signal the specificities of "whiteness" in the context of new nationalisms. Studying first in Hungary, then in the United States, Imre mentions her own experience of being warned not to compare racist violence in Hungary with racial politics in the United States. In fact, Imre does the complete opposite when she analyzes the usefulness of concepts such as colonialism and "whiteness" in a context where ethnicity, race, and the nation are deeply intertwined in central Europe. This awareness leads her to question the foundations of state formation in Hungary, as a case study, showing how "the Gypsy" trope serves to 
"expose unstable national boundaries" (Imre 2005, 86). While the foundational myth of Hungary claims that nationals were "nomads" who "settled," "Gypsies" are stigmatized as "nomadic" and "backward," frozen in time but dangerously close. She also pioneers considerations of Romani self-representation in music and film as a way to present ways to challenge prejudice through hybridity, and transnational and multicultural forms (Imre 2005, 2006, 2008).

Simultaneously, geographers in the United Kingdom explored how "whiteness" and its locally specific counterparts had actual effects on how space is understood. The first step was to note the importance of color, especially black and white, and dirtiness, to signify a threatening difference, and therefore justify exclusion of "Gypsies" (Sibley 1995, 22 and 102). The second step was actually to engage with actions that create this racial line of difference in daily life. Analysis concentrates on the mechanisms through which these stereotypes are recreated in daily life, including the "discursive efforts" of respondents who use "bodily and cultural markers" to erect boundaries in social and physical space, such as the use of "figures" of "true" or "real Gypsies," and their opposite, as a tool to racialize Romani groups among inhabitants of Appleby, where the New Fair takes place in Britain (Holloway 2005, 356).

Such awareness of representation and its relationships with social life mixed well with the so-called "Dutch School" (Willems 1997; Lucassen et al. 1998) and other pioneers of historical research (Mayall 2004) to produce more critical historiographical accounts of Romani groups (see among others: Marsh 2008; Bogdal 2012; Baumgartner and Kovács 2012). Some of these works also began to show how the assemblage of institutions and binary discourses that justified managerial interventions and strategies had deep involvement on the question of why Romani voices were excluded.

Ian Hancock's desire to put forward Romani self-organization processes and their relationship with academia also had continuation. Williams, for example, correlating travel journals with publications of budding Romani organizations in the early twentieth century in Romania, realized that scholars were appalled at the thought of Romani thinkers negotiating their position in modernity. Dealing with labels such as Romani, Tigani, Romanian, Orthodox Christian, nomad, etc., Romani thinkers became active at precisely the moment at which the Romanian nation-state was being redefined. Representatives of the GLS, on the other hand, "could not bear to think that all Roma were unconcerned with the same culture and traditions that the Gypsy Lore Society had worked so hard to 'preserve' for 60 years" (Williams 2007, 26). Although there was active communication between scholars and Romani thinkers in Romania, how could there be a constructive dialogue if the starting premises were so far apart? How could one counter the use of these racialized categorizations before they become lethal, without awareness of their role during colonialism, imperialism, and genocide?

Generational change in academia has brought the critique of power relations intrinsic to knowledge production into mainstream thought, at least in the humanities and the social sciences. In the final two sections, I show how the "Gypsy"/"non-Gypsy" divide has been addressed on two specific fronts recently. First, I will detail how accounts of Romani realities from places which go beyond the limits of the imagined "Europe" and even the "North Atlantic" have been explored. Second, I conclude by addressing how the legacy of the genealogy described above relates to the present when Romani voices have entered academia and shaken Romani Studies from its slumber. 


\section{Evidence of the Great Divide: Romani Presence in the Americas}

At this point, I deem it necessary to give an example of what can occur when Eurocentric discourses are used indiscriminately to describe Romani-lived experiences. This section contrasts different theories that have attempted to explain when and how Romani groups reached the Americas. What is required is the development of a critical eye to these theories in order to analytically decouple ideas about "Gypsies" from the actual histories of migration and mobility that resulted in Romani families making their home in the Americas. ${ }^{[6]}$

At first, scholars' main assumption was of "nomadism" as opposed to "sedentarism," an almost inseparable characteristic of the "Gypsy." Early accounts of Romani groups in South America, such as those of Irving Brown (1938), assumed that the terms "nomad" and "Gypsy" were interchangeable. As such, the presence of Romani groups in the Americas was naturalized: they arrived because of their predisposition to move, and their mobile practices could be explained by the same totalizing logic. Even pioneers of the sociology of migration, such as Robert Park, considered this as a "geographical fact" that spoke of "ancient tribal organization and customs" (Park 1928, 887). This changed over time, however, especially when the category became the center of ethnographic analysis. Unfortunately, a "Gypsy"/"non-Gypsy" binary persisted in many of these more sophisticated analyses. ${ }^{[7]}$

In the 1990s, as the fall of the Iron Curtain was followed by East-West migration in Europe, Migration Studies became the dominant way to explain Romani population movements (Guy et al. 2004, 12). Migrant groups were considered to have a "sedentary" present but a "nomadic" past. That way their present mobilities could be explained by more refined lenses such as economic reasons or violent displacement, without upsetting the trope. A good example of how this teleological thought is still present are Marushiakova and Popov's recent models of the different "waves" of Romani population in Europe. Centuries worth of movement are summarized in three stages: (1) a "nomadic community" successfully "acquiring niches" in fifteenth century Europe; (2) a "nomadic invasion" from Eastern Europe during the nineteenth century, escaping "from the freedom, and the [...] new citizen obligations and responsibilities" that resulted from the abolition of slavery in Wallachia and Moldavia; and (3) a "third migration wave" from the 1960s onward, which could be better explained by labor migration (Marushiakova and Popov 2010, 126-128).

6 It is important to point out that this specific section does not intend to reinforce ideas around Romani people being eternal "nomads," "migrants," or "vagrants," as has been commonplace since the nineteenth century. The assumption that Romani groups have no attachment to place is contrary to what I argue here and in my doctoral thesis: that is, the need to revalue Eurocentric metaphors with little or no real grounding on histories, practices, and experiences of actual embodied mobilities and im/mobilities of Romani individuals and groups.

7 Since the 1970s academics have tried to pin down the relationship between the "nomad" label and the particular daily practices of diverse Romani groups. For a more detailed analysis on this subject, see Acuña 2018. 
In the last few decades, this particular model has been reproduced by academics who have wished to understand Romani presence in the Americas. Most works ${ }^{[8]}$ that have tried to contextualize ethnographic fieldwork in Latin American countries, for example, have used a similar version of the "wave" model summarized by Anne-Isabelle Lignier as: (a) a first "wave" during the colonial period (fifteenth to eighteenth century) (Lignier 2012, 11); (b) a second "wave" during the nineteenth century that corresponded not only to the end of slavery but to the intensification of persecution in Western Europe and the Great Migration $(2012,14)$. This "wave" ends with the First World War and the disintegration of the Austro-Hungarian Empire, another motivation for migration (2012, 15-16). (c) The third "wave" coincides with the Second World War, and the displacement caused by genocide that included Romani groups from all states under Nazi occupation $(2012,16)$. Finally, (d) a fourth "wave" commences with the fall of the Berlin Wall and the war in ex-Yugoslavia and continues until today $(2012,16)$. Although the authors have tried to adapt the model to their own work in the field and the number of "waves" has increased over time - this example has four and more recently six "waves" (Baroco and Lagunas 2014) the imposition of a European model seems apparent for two reasons:

1. The "wave" corresponds to what Schapendonk has called "frictionless metaphors of migration" (2012, 27-28), which create neat unidirectional models with cartographic appeal. However, they do not reveal much information about how journeys and lives actually took and take place. They act much like the "nomad" metaphor to explain mobile practices, reproducing the "Gypsy"/"non-Gypsy" divide by building a framework where actual experiences are out of the picture, including details of migratory and mobile practices and histories.

2. More pertinent to this article, this model, which allegedly fits an entire continent, is transposed from European historical categorizations without much reflection on how the actual histories of Romani families that embarked and continue embarking on journeys across the Atlantic relate to it. The actual lived experiences and contexts in the Americas continue to resist the transposition of Eurocentric understandings of transnational movements.

Ronald Lee also struggled with these trends in the representation of Romani migration. Early in his career, Lee argued, "The North American Gypsy is not nomadic for the most part but he is mobile" $(1967,40)$, referring to mobile strategies in daily life among the groups he knew as well as in his own life. As the new arrivals of asylum seekers shifted his own interests, Lee also refined his classifications of "Romani immigration to Canada" focusing this time on particular groups themselves and the period of their arrival. He mentions (a) "Vlach Roma from Eastern Europe and the Balkans" who arrived during the nineteenth century (Lee 2000, 2); (b) "another group which trekked up to Canada from Argentina via Mexico and the United States" around the same time (2000, 2); (c) "British-Romani Travellers" who arrived in the second decade of the twentieth century; (d) "some Romani families of Sinti and Romungere [...] from Germany and the Austro-Hungarian Empire" who arrived before the First World War; (e) "sedentary Hungarian Romungere, mainly of the Bashaldé or musician groups who arrived as refugees, lost among the mass of non-Romani Hungarian refugees fleeing the Russian invasion of 1956"

8 See Acuña (forthcoming) for a more thorough account of the use of the "wave" and other models by authors who work with Romani groups in Central and South America. 
$(2000,3)$; and (f) the recent "Roma who were now forced to flee these former communist countries because of systematic discrimination and the rise of neo-Nazi groups, fear of skinhead violence, ethnic cleansing and overt persecution at the hands of governments and police" $(2000,4)$. Families that could formerly pass as "fleeing communism" now had to engage in a new regime of visibility, by making their claim "based on their Romani ethnicity" (ibid.).

The "wave" model clashed with Lee's experiences, as reality is an amalgam of continuous and diverse movements, connections, arrivals, and moorings, including practices of home and place-making. From the nineteenth century alone, six different trends of transnational movements of Roma are enumerated, which respond not only to European politics and trends but also to movements of families in the Americas. In his work, Romani experiences and thoughts meet academic presuppositions in conflicting but productive ways, feeding off the continuity of Romani mobilities and presence in the Americas. As Argentinian Romani activist Jorge Bernal summarized: "Contacts are also maintained with many European countries, including Germany, Spain, Sweden and France. Aside from others where the LatinAmerican Rom have relatives and travel often, this allows the Romani people to keep the language and culture alive through permanent contacts with relatives abroad" (Bernal 2003, 6). Lee and Bernal were already following Brazilian anthropologists Fotta and Ferrari's advice one decade before: "the history and culture of Gypsies cannot be understood without taking the transatlantic space into account" $(2014,114)$.

\title{
4. Waking up Romani Studies or the "Gadje Awakening": The Importance of Romani Thought and Transatlantic Critical Awareness
}

\author{
“The Gypsy Beast must be detoothed, declawed, and neutered before it can enter the hallowed \\ halls of academia."
}

Ronald Lee, Facebook commentary, April 22, 2018.

The journal Critical Romani Studies, which began publishing in 2018, has gathered exponents who have actively shown the productive cross-fertilization to which I refer. It is important then to give a nod to some of the trends that have resulted from such exchanges and keep adding insights on how to deal with Eurocentric logics in our daily work as researchers:

(1) A promising trend that appeared a decade ago takes the critical insights both on knowledge as power and on knowledge creation as a site of hegemony and domination and brings them to contemporary developments around "Roma rights" in Europe (Trehan 2009; Trehan and Koczé 2009). Relying on postcolonial and subaltern studies, these works have focused on the rise of "NGOization," US-based private foundation funding, and "American-style discourses on civil liberties and human rights" (Trehan 2009, 16) - all structures and institutions that have brought their own hierarchies and sites of violence. The reader can appreciate the irony of this convoluted side of transatlantic exchanges, which in this case reproduces the 
assumption that there is a gap between "Roma" and European societies by imposing models that create new elites, which Trehan calls "human right entrepreneurs."

(2) Second, Koczé (2011) and Oprea (2004) have proposed an intersectionality framework that incorporates a refined awareness of issues of race, class, and gender. This has been developed in order to understand and challenge the marginalization of Romani women from the construction of knowledge in Romani Studies, including the naturalization of patriarchal structures and privilege as part of "Gypsyness." These seminal works paved the way for Romani feminism, noting the historical downplay of "the strong multinational, multigenerational networks that Romani women have formed over the past decade to fight the multiple modes of discrimination that permeate every area of life" (Brooks 2012,6) and the exclusion that ensues.

(3) Finally, Petra Gelbart ${ }^{[9]}$ and Heather Tidrick (2010) also talked provocatively of "gadjology" or "gadzology", an inversion that marks the importance of "from a Romani-informed point of view, systems, structures, and discourses controlled by non-Roma and how they shape the lives and possibilities of Romani persons" (Tidrick 2010, 127). The inversion of the binary has been the next step towards acknowledging power relations, after critical approaches to "whiteness" move towards taking a stance on "ethnography-as-activism" and away from imposed models that have little to do with Romani experiences and thoughts and towards alternative, perhaps anti-hegemonic, narratives.

I consider that this article adds to the epistemological debates in Romani Studies by, first, weaving a timeline of critical approaches to the discipline before the appearance of the CRS journal. Coinciding with the fortieth anniversary of Edward Said's Orientalism, it revisited his influence on Romani Studies, especially in the identification of the role of the oppositional divide between "Gypsies" and "nonGypsies" in the construction of knowledge on, about, and from Romani groups. In order for this to be accomplished, I built a genealogy since the first appearances of critical studies of representation in this line of academic work until the beginning of the twenty-first century.

The first aspect of the divide that was explored was that of the "Gypsy" as premodern and opposed to civilization. This notion is later expanded to consider how the "Gypsy" is conceived as outside of "the West," outside of its time, history and literature, and used to justify regulation, control, and unequal power relations. Even further down this path, some works noted how academic institutions were part of the powerful apparatus of internal colonialism in Europe. The beginning of the twenty-first century would be the moment in which ethnographers, on the shoulders of these developments, used the concepts of performance and performativity to describe quotidian engagement with these tropes in different daily life contexts. The marginal academic path of representation critique later became the basis for an evergrowing and progressively more influential set of works on the subject, and a foundation for the ongoing discussions highlighted in this journal.

9 See: P. Gelbart. 2011. “Gadjology: a Brief Introduction.” Presented at the Inaugural Romani Studies Conference at University of California Berkeley, Nov 10. https://www.youtube.com/watch?v=cup3fwqsoLE 
In the Facebook comment taken as this section's epigraph, Ronald Lee expresses his well-justified distance and suspicion of the entrance of Romani thought and experience into scholarship. The "Gypsy Beast" supposedly must be quelled when it dares to enter the white towers of academia. This image is particularly powerful when we see how the present situation of Romani Studies has been understood: as a "Roma Spring" or "Roma Awakening." ${ }^{10]}$ Indeed, it was a moment which not-so-innocently coincided with the end of the European Union's Decade of Roma Inclusion (DRI) in 2015. Initially perceived as the necessary solution for "eliminating discrimination and closing the unacceptable gaps between Roma and the rest of society," the Decade had the task to achieve two objectives: "Accelerate progress toward improving the welfare of Roma by including Roma in the decision-making process" and "[...] review such progress in a transparent and quantifiable way." Applying Lee's suspicion, it is quite noticeable how this talk of "inclusion" has a familiar undertone of a "Gypsy"/"non-Gypsy" divide. Coinciding with its end, the "Roma Awakening," as Andrew Ryder argues, has been characterized by aggressive debates and positioning concerning the "relations between civil society, academia and Roma communities."[11] These discussions have included critical positions on the way the Decade contributed to skewed representation(s) of Romani people. It would take too long, though, to note here the strong reactions that such an "awakening" has provoked; paraphrasing Lee, the "Gypsy Beast" has awoken, and now academia shakes in distress.

This article could also be understood as another contribution to acknowledging that "the Gypsy Beast," as opposed to the "immaculate halls of academia," does not exist beyond its use as part of western geographies of imagination. Perhaps it is Romani Studies that has awoken from its century-long slumber. The field is now driven by Romani thought and experiences that have slowly but firmly raised awareness of the powerful lenses that guide knowledge creation in the field.

A second contribution that stems from this realization is that transatlantic mobilities, connections, and circulations have been a constant but marginal reminder of underlying Eurocentrism and have the potential to critically inform our current stances. The contributions of who I call, perhaps oversimplistically, transatlantic scholars, both Romani and non-Romani, have cemented new and exciting possibilities of inquiry beyond the imagined limits of Europe and European thought (and even beyond the North Atlantic). Not coincidentally, most of the authors whose work has been included here have had opportunities to travel between epistemic contexts, many times mentioning them in their own work. Ronald Lee is a good example of this productive tension, since his reflections have not only added theoretical insights to the field but also refined empirical stances, as my detour through theories of Romani presence in the Americas attests.

I do not claim to have made an exhaustive review since that qualifies as homework yet to be done. I do, however, aim at raising awareness of Eurocentric ideas in our midst. As a corollary, scholars are urged to take advantage of our own trans-local positionalities, and those of the respondents that kindly give us

10 A. Ryder. 2015. “The Roma Awakening.” European Roma Rights Center Blog. http://www.errc.org/blog/the-roma-awakening/60 11 DRI (2010 [2005]). Decade of Roma Inclusion 2005-2015. Terms of Reference. Sofia. 
their time and thoughts - and, at least in the case of my respondents, a generosity always accompanied by a healthy dose of distance and suspicion - to continue advancing the multiplicity of critical stances that have characterized this new "gadje awakening."

\section{References}

Acuña Cabanzo, Esteban. 2018. Romani Mobilities as Resilience Tactics and Strategies: Trans-Atlantic Expectations, Lives and Journeys. In Transnational Resilience and Change: Gypsy, Roma and Traveller Strategies of Survival and Adaptation, edited by Dan Allen, Margaret Greenfields, David Smith. Newcastle upon Tyne: Cambridge Scholars Press.

- Forthcoming. Tracing the Romani Atlantic: An Ethnography of Trans-local Interconnections and Mobilities among Romani Groups. Doctoral Dissertation. Freiburg University.

Baroco, Fernando. and David Lagunas. 2014. Another Otherness. The Case of the Roma in Mexico. In Masks of Identity: Representing and Performing Otherness in Latin America, edited by Premysl Mácha and Eloy GómezPellón. Newcastle upon Tyne: Cambridge Scholars Publishing.

Baumgartner, Gerhard, and Éva Kovács. 2012. "The Gaze of Bourgeois Society and Enlightenment on the Roma and Sinti." Unpublished.

Bernal, Jorge. 2003. The Rom in the Americas. Commission on Human Rights. United Nations. http://www.prolades.com/urban_lam/buenos_aires/romani_arg.pdf.

Bogdal, Klaus-Michael. 2012. “Europe Invents the Gypsies. The Dark Side of Modernity.” Translated by Christopher Gilley. Eurozine. February 24. https://www.eurozine.com/europe-invents-the-gypsies.

Brooks, Ethel C. 2012. “The Possibilities of Romani Feminism.” Signs 38 (1): 1-11. https://doi.org/10.1086/665947.

Brown, Irving. 1938. “Gypsies in South America." Gypsy Lore Society Journal 3 (17): 1-8.

Chakrabarty, Dipesh. 2000. Provincializing Europe. Postcolonial Thought and Historical Difference. Princeton: Princeton University Press.

Dearing, Stewart. 2010. Painting the Other Within. Gypsies according to the Bohemian Artist in the Nineteenth and Early Twentieth Centuries. Romani Studies 520 (2): 161-202. https://doi.org/10.3828/rs.2010.7.

Fabian, Johannes. .2002. Time and the Other. How Anthropology Makes its Other. New York: Columbia University Press. https://doi.org/10.7312/fabi16926.

Ferrari, Florencia, and Martin Fotta. 2014. "Brazilian Gypsiology. A View from Anthropology.” Romani Studies 524 (2): 111-136. https://doi.org/10.3828/rs.2014.6.

Gilroy, Paul. 1993. The Black Atlantic. Modernity and Double Consciousness. London: Verso. https://doi.org/10.1093/ oxfordhb/9780198717133.013.55.

Glajar, Valentina, and Domnica Radulescu, eds. 2008. "Gypsies" in European Literature and Culture. New York: Palgrave Macmillan (Studies in European Culture and History). https://doi.org/10.1057/9780230611634.

Gropper, Rena C., and Carol Miller. 2001. "Exploring New Worlds in American Romani Studies. Social and Cultural attitudes among the American Macvaia." Romani Studies 511 (2): 81-110.

https://doi.org/10.3828/rs.2001.5.

Guy, Will, Zdenek Uherek, and Renata Weinerova, eds. 2004. Roma Migration in Europe. Case Studies. Münster: Lit Verlag Münster. 
Hall, Stuart. 2003. The Spectacle of 'The Other'. In Representation. Cultural Representations and Signifying Practices, edited by Stuart Hall. London: SAGE Publications.

Hancock, Ian. 1991 “The East European Roots of Romani Nationalism.” Nationalities Papers 19 (3): 251-267. https://doi.org/10.1080/00905999108408203.

—. 1997. "The Struggle for the Control of Identity. Transitions 4 (4). http://www.oocities.org/ patrin/identity.htm.

- 2010. Danger! Educated Gypsy. Selected Essays. University of Hertfordshire Press.

Holloway, Sarah L. 2005. “Articulating Otherness? White Rural Residents Talk about Gypsy-Travellers.” Transactions of the Institute of British Geographers 30 (3): 351-367. https://doi.org/10.1111/j.14755661.2005.00176.x.

Imre, Aniko. 2005. Whiteness in Post-Socialist Eastern Europe: The Time of the Gypsies. The End of Race. In Postcolonial Whiteness. A Critical Reader on Race and Empire, edited by Alfred J. Lopez, 79-102. Albany: State University of New York Press. https://doi.org/10.1002/9781119118589.ch18.

_ 2006. "Play in the Ghetto. Global Entertainment and the European 'Roma Problem. '” Third Text 20 (6): 659-670. https://doi.org/10.1080/09528820601068781.

- 2008. Roma Music and Transnational Homelessness. Third Text 22 (3): 325-336. https://doi.org/10.1080/09528820802204664.

Kóczé, Angéla. 2011. Gender, Ethnicity and Class. Romani Women's Political Activism and Social Struggles. Central European University. Budapest. PhD Dissertation. Department of Sociology and Social Anthropology.

Lee, Ken. 2000. “Orientalism and Gypsylorism.” Social Analysis 44 (2): 129-156.

Lee, Ronald. 1967. “The Gypsies in Canada.” Journal of the Gypsy Lore Society. 46: 38-51.

_ 2007. "Post-communism Romani Migration to Canada." Cambridge Review of International Affairs. 13 (2): 51-70 https://doi.org/10.1080/09557570008400298.

Lemon, Alaina. 2000. Between Two Fires. Durham: Duke University Press. https://doi.org/10.1215/9780822381327.

Lignier, Anne-Isabelle. 2012. "L'Odyssée méconnue des Tsiganes en Amérique latine." Etudes Tsiganes 51: 10-24. https://doi.org/10.3917/tsig.051.0008.

Lucassen, Leo, Wim Willems, and Annemarie Cottaar. 1998. Gypsies and Other Itinerant Groups. A Socio-historical Approach. Basingtoke: Palgrave. https://doi.org/10.1007/978-1-349-26341-7.

Lyon, Janet. 2004. “Gadze Modernism.” Modernism/Modernity 11 (3):. 517-538. https://doi.org/10.1353/mod.2004.0061.

Marsh, Adrian. 2008. "No Promised Land." History, Historiography \& The Origin of the Gypsies. PhD Thesis. University of Greenwich London. Sociology Department.

Matras, Yaron. 2004. The Role of Language in Mystifying and Demystifying Gypsy Identity. In The Role of the Romanies. Images and Counter Images of 'Gypsies'/Romanies in European Cultures, edited by Nicolas Saul and Susan Tebbutt. Oxford: Oxford University Press. https://doi.org/10.5949/upo9781846313950.

Mayall, David. 2004. Gypsy Identities 1500-2000. From Egipcyians and Moonmen to Ethnic Romany. London: Routledge. https://doi.org/10.4324/9780203490051.

Okely, Judith. 1983. The Traveller-Gypsies. Cambridge: Cambridge University Press. https://doi.org/10.1017/cbo9780511621789.010. 
. 2011. "Retrospective Reading of Fieldnotes. Living on Gypsy Camps." Behemoth 4 (1). https://doi.org/10.1515/behemoth.2011.003.

. 2014. "Recycled (Mis)representations. Gypsies, Travellers or Roma Treated As Objects, Rarely Subjects." People, Place and Policy 8 (1): 65-85. https://doi.org/10.3351/ppp.0008.0001.0006.

Oprea, Alexandra. 2004. "Re-envisioning Social Justice from the Ground up: Including the Experiences of Romani Women." Essex Human Rights Review 1 (1): 29-39.

Park, Robert E. 1928. "Human Migration and the Marginal Man." American Journal of Sociology 33 (6): 881-893. https://doi.org/10.1007/978-1-349-24984-8_10.

Said, Edward. 2003 (1978). Orientalism. London: Penguin Books.

Saul, Nicolas, and Susan Tebbutt, eds. 2004. Role of the Romanies. Images and Counter Images of 'Gypsies'/Romanies in European Cultures. Oxford: Oxford University Press. https://doi.org/10.5949/upo9781846313950.

Schapendonk, Joris. 2012. "Turbulent Trajectories. African Migrants on their Way to the European Union." Societies 2: 27-41. https://doi.org/10.3390/soc2020027.

Selling, Jan. "Assesing the Historical Irresponsibility of the Gypsy Lore Society in Light of Romani Subaltern Challenges.” Critical Romani Studies 1 (1): 44-61. https://doi.org/10.29098/crs.v1i1.15.

Sibley, David. 1995. Geographies of Exclusion. Society and Difference in the West. London: Routledge. https://doi.org/10.4324/9780203430545.

Sigona, Nando, and Roger Zetter. 2010/ Conference Proceedings. Romani Mobilities in Europe: Multidisciplinary Perspectives. Romani Mobilities in Europe: Multidisciplinary Perspectives International Conference. Refugee Studies Centre, University of Oxford.

Sonneman, Toby F. 1999. “Dark Mysterious Wanderers. The Migration Metaphor of the Gypsy.” Journal of Popular Culture 32: 119-139. https://doi.org/10.1111/j.0022-3840.1999.00119.x.

Stewart, Michael. 2013. Roma and "Gypsy" Ethnicity as a Subject of Anthropological Inquiry. Annual Reviews in Anthropology 42: 415-432. https://doi.org/10.1146/annurev-anthro-092010-153348.

Taussig, Michael. T. 1987. Shamanism, Colonialism, and the Wild Man. A Study in Terror and Healing. Chicago: University of Chicago Press. https://doi.org/10.7208/chicago/9780226790114.001.0001.

Tidrick, Heather. (2010) "Gadzology as Activism. What I Would Have Ethnography Do for East European Roma." Collaborative Anthropologies 3: 121-131. https://doi.org/10.1353/cla.2010.0012.

Trehan, Nidhi. 2009. Human Rights Entrepreneurship in Post-socialist Hungary: From the 'Gypsy Problem' to "Romani Rights" (Doctor of Philosophy). University of London, London.

Trehan, Nidhi, and Angéla Kóczé. 2009. Racism, (Neo)colonialism and Social Justice. The Struggle for the Soul of the Romani Civil Rights Movement in the "New Europe." In Racism, Post-colonialism, Europe, edited by Graham Huggan and Ian Law, 50-77. Liverpool: Liverpool University Press.

https://doi.org/10.5949/liverpool/9781846312199.003.0004.

Trouillot, Michel-Rolph. 2003. Global Transformations. Anthropology and the Modern World. New York: Palgrave Macmillan. https://doi.org/10.1007/978-1-137-04144-9.

Trumpener, Katie. 1992 “The Time of the Gypsies. A 'People without History' in the Narratives of the West." Critical Inquiry 18 (4): 843-884. https://doi.org/10.1086/448659.

Van de Port, Mattijs. 1999. “The Articulation of Soul. Gypsy Musicians and the Serbian Other." Popular Music 18 (3): 291-307. https://doi.org/10.1017/s0261143000008886. 
Wells, Deborah. 1962. "Best Petty Thieves in the World." Montreal Star. October 1962.

Willems, Wim. 1998. In Search of the True Gypsy. From Enlightenment to Final Solution. London: Routledge. https://doi.org/10.4324/9781315810225.

Williams, Susan. 2007. “The 'Civilized Trap' of Modernity and Romanian Roma, 1918-1934.” Anthropology of East Europe Review 26 (1): 12-27. 